\title{
ANALYSIS OF TOTAL FLAVONOID LEVELS IN BROWN ALGAE (SARGASSUM SP. AND PADINA SP.) AS ANALGESIC DRUG THERAPY
}

\author{
RUSLIN $M^{1 *}$, AKBAR FUAD HUSAIN ${ }^{2}$, HAJRAH-YUSUF AS ${ }^{1}$, SUBEHAN ${ }^{3}$ \\ ${ }^{1}$ Department of Oral and Maxillofacial Surgery, Faculty of Dentistry Hasanuddin University, Makassar, Indonesia. ${ }^{2}$ Department of Dental \\ Public Health, Faculty of Dentistry Hasanuddin University, Makassar, Indonesia. ${ }^{3}$ Laboratory of Phytochemistry, Faculty of Pharmacy \\ Hasanuddin University, Makassar, Indonesia. Email: mruslin@unhas.ac.id
}

Received: 07 March 2018, Revised and Accepted: 02 April 2018

ABSTRACT

Objective: Brown algae is one of the most interesting phyla that consist of pharmacologically active compounds and have been widely studied in recent years. One of the active compounds contained in brown algae that are known to have an analgesic effect is flavonoids. The aim of this study is to analyze the total amount of flavonoid compound in Sargassum sp. and Padina sp. as an analgesic drug.

Methods: Samples used in this study were brown algae Sargassum sp. and Padina sp. taken from the Punaga Ocean, Takalar, South Sulawesi. The samples were extracted using the maceration method. After the extraction procedure, the total flavonoid levels were measured using a quercetin standard curve at maximum frequency.

Results: Based on the measurement results, the total flavonoid levels in Sargassum sp. are $1.428 \% \pm$ sSD $0.168 \%$.

Conclusion: Padina sp. has higher total flavonoid levels compared to Sargassum sp. and can potentially act as an analgesic drug.

Keywords: Analgesics, Brown algae, Flavonoids.

(c) 2018 The Authors. Published by Innovare Academic Sciences Pvt Ltd. This is an open access article under the CC BY license (http://creativecommons. org/licenses/by/4. 0/) DOI: http://dx.doi.org/10.22159/ajpcr.2018.v11i7.25657

\section{INTRODUCTION}

Indonesia is a country known for its abundant natural resources and very extensive sea areas. Approximately $78 \%$ of the Indonesian territory is covered by water with shallow and deep seas [1]. As an archipelagic country with large areas for seaweed cultivation $(11,109$ $\mathrm{km}^{2}$ ), Indonesia is endowed with an abundance of tropical seaweed resources [2]. Several studies have shown that marine organisms, seaweed, and marine algae provide a high source of bioactive secondary metabolites that may be useful in the development of new pharmaceutical agents $[3,4]$. However, until now, marine algae in coastal areas of Indonesia have been neglected, especially in the pharmacological area [1-3].

Marine algae is classified into several types based on the composition of nutrients, pigments, and chemicals, such as Rhodophyta (red algae), Phaeophyta (brown algae), and Chlorophyta (green algae). This marine algae has been considered safe, non-toxic, easy to find, and its availability is not limited to various fields [3,4]. A number of pharmacological activities have been reported on marine algae, for example, antitumor, cytotoxic antioxidants, anthelmintic, anticoagulant, antibacterial, antifungal, hepatoprotective effect, and inhibiting DNA polymerase and xanthine oxidase [4,5]. A study by Hong et al. using Sargassum fulvellum and Sargassum thunbergii indicated the presence of antipyretic, analgesic, and anti-inflammatory activity in mice [6]. In another study conducted by Thennarasan et al., the analgesic effects of brown algae extract from Lobophora variegata showed significant analgesic activity when used in rats induced by chemical stimulants [7].

Although some studies have shown the analgesic activity of brown algae, until now, there is a little to no information available on the analgesic effect of the Sargassum sp. and Padina sp. of brown algae. Recent studies on Sargassum sp. and Padina sp. have primarily focused on anti-inflammatory and hemostatic effects in wound healing. Based on this fact, this study aims to analyze the flavonoid content of brown algae that serves as an analgesic as well as comparing the types of brown algae (Sargassum sp. and Padina sp.) that have the best analgesic effect.

\section{METHODS}

This type of research is experimental laboratory with post-test design with control group design. This research was conducted at Laboratorium Biofarmaka Hasanuddin University Faculty of Pharmacy in May 2017. The population of this research is brown algae that grows in Punaga waters, Takalar Regency, South Sulawesi Province. The samples used are Sargassum sp. and Padina sp. Sampling was done using a convenience sampling method.

Preparation of the extracts was done using the maceration method until dense extracts of Sargassum sp. and Padina sp. were obtained. Total flavonoid measurements were performed in triplicate at three different concentrations: $150 \mathrm{ppm}, 300 \mathrm{ppm}$, and $450 \mathrm{ppm}$. The total flavonoid content of Sargassum sp. and Padina sp. was determined using colorimetric methods with $\mathrm{AlCl}_{3}$ reagents and spectrophotometry with a standard blank ratio in the laboratory.

Based on the total flavonoid measurement data, a quercetin calibration curve was made resulting in the equation $y=0.078 x+0.029\left(R^{2}=0.994\right)$, where $\mathrm{y}$ is the absorbance value and $\mathrm{x}$ is the quercetin content. Using the quercetin calibration curve, absorbance measurements of Sargassum sp. and Padina sp. samples were used to determine the total flavonoid levels.

\section{RESULTS}

The total flavonoid level in Sargassum sp. and Padina sp. samples was determined after absorbance measurements and reported in Tables 1 and 2 , respectively. 
Table 1 shows the total flavonoid content in Sargassum sp. samples at three concentrations, each performed in triplicate. The average total flavonoid level in the $150 \mathrm{ppm}$ sample is $1.237 \pm 0.158 \%$, in the $300 \mathrm{ppm}$ sample is $1.492 \pm 0.156 \%$, and in the $450 \mathrm{ppm}$ sample is $1.553 \pm 0.087 \%$.

Table 2 shows the total flavonoid content from Padina sp. samples at three concentrations, each performed in triplicate. The average total flavonoid level in the $150 \mathrm{ppm}$ sample is $2.318 \pm 0.135 \%$, in the $300 \mathrm{ppm}$ sample is $2.376 \pm 0.092 \%$ and in 450 ppm sample is $2.375 \pm 0.091 \%$.

Table 3 shows the total flavonoid content in Sargassum sp. samples and Padina sp. samples at each concentration measured. Table 3 shows that the flavonoid content of the Padina sp. is higher than the Sargassum sp. at the concentration $150 \mathrm{ppm}, 300 \mathrm{ppm}$, and $450 \mathrm{ppm}$. This account means that the flavonoid content in the Padina sp. is higher than in the Sargassum sp.

\section{DISCUSSION}

The levels of flavonoids in herbal samples can be determined by various methods. In this study, a 70\% ethanol solvent was used in the algae extraction process because it has the ability to find compounds in a wide range of polarities, it is not as toxic as other organic solvents, and it is effective in finding active compounds [8]. A research by Asnani et al. found that the method of extraction and the type of solvent used did not affect the flavonoid content [9]. The authors agree with this because the structure of flavonoids has an equal amount of polar and non-polar parts and does not depend on the type of solvent used.

Based on the results of this study, the content of flavonoids in Sargassum sp. extract is $1.428 \% \pm$ SD $0.168 \%$ while the content of flavonoids in Padina sp. is $2.357 \% \pm$ SD $0.025 \%$. These study are in line with the results of phytochemical tests performed by Margaret and Marie, and both studies found the presence of flavonoid compounds contained in brown algae type Sargassum sp. and Padina sp. [10,11]. Another study by Nurjanah et al. found that Sargassum sp. and Eucheuma cottonii contain active components that are thought to have potential as a raw material for the manufacturing of drugs and cosmetics. These components are thought to be flavonoids, phenols hydroquinone, and triterpenoids [12].
In this study, the measurement results showed that Padina sp. and Sargassum sp. have effective analgesic activity as a pain reliever based on the content of flavonoids they contain. This is supported in research conducted by Thennarasan et al. who tested the analgesic effects of algae extracts from brown type L. variegata. This study found that the content of flavonoids in algae can reduce pain by reducing prostaglandins [7]. Another study by Simpi et al. found that Sargassum ilicifolium is able to relieve pain by producing acetic acid which allows seaweed to produce its analgesic activity both peripherally and centrally [5].

In the results of this study, it was found that the flavonoid content Padina sp. extracts are higher than in the Sargassum sp. extracts and they can serve as an analgesic. Flavonoids are efficacious as analgesics whose mechanism of action inhibits cyclooxygenase enzyme action [13]. This is supported in research by Asmawati et al. who found that brown algae Padina sp. and Sargassum sp. contain flavonoids with good antiinflammatory biological activity [14].

Brown algae is a source of bioactive secondary metabolites rich in steroids, flavonoids, glycosides, alkaloids, and insecticides. These active metabolites that have large drug values, and therefore, this herb plant and its products can be used to cure various diseases because it has no side effects compared to pharmaceutical drugs [15]. The findings in this study reinforce claims in the health and medicine industry that seaweed can be used as a solution to various symptoms related to inflammation.

\section{CONCLUSION}

Both Padina sp. and Sargassum sp. have a total flavonoid content that can act as an analgesic drug. Padina sp. is suspected to have more effective analgesic activity than Sargassum sp. in terms of total flavonoid concentration. Since levels of flavonoids measured in this study are total flavonoid levels, further research on the composition of other active substances in Sargassum sp. and Padina sp. which can act as analgesic drugs needs to be done.

\section{ACKNOWLEDGMENT}

Authors would like to thank the local resident of Punaga District, Takalar Regency, who helped us in collecting samples (Sargassum sp. and Padina sp.) for the studies. We are also grateful to the Dean

Table 1: The total flavonoid content of Sargassum sp. using $\mathrm{AlCl}_{3}$ reagent

\begin{tabular}{llll}
\hline Concentration & Replication & Absorbance & Total flavonoid level (\%) \\
\hline $150 \mathrm{ppm}$ & I & 0.148 & 1.114 \\
& II & 0.156 & 1.182 \\
& III & 0.184 & 1.415 \\
$300 \mathrm{ppm}$ & I & 0.328 & 1.318 \\
& II & 0.380 & 1.538 \\
& III & 0.399 & 1.620 \\
$450 \mathrm{ppm}$ & I & 0.531 & 1.453 \\
& II & 0.588 & 1.613 \\
\end{tabular}

SD: Standard deviation

Table 2: The total flavonoid content of Padina sp. using $\mathrm{AlCl}_{3}$ reagent

\begin{tabular}{llll}
\hline Concentration & Replication & Absorbance & Total flavonoid level (\%) \\
\hline $150 \mathrm{ppm}$ & I & 0.273 & 2.167 \\
& II & 0.303 & 2.429 \\
& III & 0.295 & 2.357 \\
$300 \mathrm{ppm}$ & I & 0.588 & 2.420 \\
& II & 0.553 & 2.271 \\
& III & 0.592 & 2.439 \\
$450 \mathrm{ppm}$ & I & 0.876 & 2.429 \\
& II & 0.820 & 2.270 \\
\end{tabular}

SD: Standard deviation 
Table 3: A comparison of mean total flavonoid content between samples of Sargassum sp. and Padina sp. at each concentration

\begin{tabular}{lll}
\hline Concentration & \multicolumn{2}{l}{ Flavonoid level (\%) } \\
\cline { 2 - 3 } & Sargassum sp. & Padina $\mathbf{~ s p . ~}$ \\
\hline $150 \mathrm{ppm}$ & $1.237 \pm 0.158$ & $2.318 \pm 0.135$ \\
$300 \mathrm{ppm}$ & $1.492 \pm 0.156$ & $2.376 \pm 0.092$ \\
$450 \mathrm{ppm}$ & $1.553 \pm 0.087$ & $2.375 \pm 0.091$ \\
\hline
\end{tabular}

of Faculty of Dentistry Hasanuddin University and the Vice-Rector for Education of Hasanuddin University for their support and assistance.

\section{AUTHORS' CONTRIBUTION}

This work was done by the authors named in this article and all liabilities pertaining to claims relating to the content of this article will be borne by the authors. M. Ruslin, Fuad Husain Akbar, and A. St. Hajrah Yusuf collected the data, analyzed the data, and wrote the introduction, discussion, and the material and method part. Subehan helped in all the laboratory work, performed, and designed the study.

\section{CONFLICTS OF INTEREST}

The authors declare no conflict of interests of this study.

\section{REFERENCES}

1. Hutomo M, Moosa MK. Indonesian marine and coastal biodiversity: Present status. Indian J Mar Sci 2005;34:88-97.

2. Heti M, Geldermann J. Managing risks in the Indonesian seaweed supply chain. Clean Techn Environ Policy 2017;19:175-98

3. Kathiravan V, Panneerselvam N, Palanikumar L. An untapped resource for natural anti-inflammatory compounds from marine macroalgae. Int J Pharm Bio Sci 2015;6:579-95.

4. Oliveira NM, Meira CL, Aguiar RM, Oliveira DM, Moura CW,
Filho SA. Biological activities of extracts from padina boergesenii and SargassumStenophyllum, seaweeds naturally found in Baia de Todos os Santos, Brazil. Int J Pharm Pharm Sci 2015;7:350-3.

5. Simpi CC, Nagathan CV, Karajgi SR, Kalyane NV. Evaluation of marine brown algae Sargassum ilicifolium extract for analgesic and anti-inflammatory activity. Pharm Res 2013;5:146-9.

6. Hong DD, Hien HM, Anh HT. Studies on the analgesic and antiinflammatory activities of Sarrgassum swartzii(Turner) C. Agardh (Phaeophyta) and unlva reticulateforsskal (Chlorophyta) in experimental animal models. J Biotechnol 2011;10:2308-14

7. Thennarasan S, Murugesan S, Chidambaranathan N, Sivamurugan V. Analgesic, anti-inflammatory and antipyretic activity of the methanol extracts of brown alga Lobophora variegate (J.V.Lamouroux) womersley ex e.c.oliveir. Am J Phytomed Clin Ther 2016;4:42-57.

8. Utami YP, Umar AH, Ernawati E. Analysis of total anthocyanin content on ethanol extract of purple sweet potato (Ipomoea batatas L.) and purple yam (Dioscoreaalata L.) with differential $\mathrm{pH}$ method. J Pharm Med Sci 2016;1:1-4.

9. Asnani A, Septiana AT. The study of phytochemical properties of brown seaweed extract Sargassum duplicatum using a variety of solvents and methods of extraction. Arointek 2012;6:22-8.

10. Margareth M. Sargassum sp. Seaweed extraction and extract testing as tyrosinase inhibitors. Repository IPB 2014:10.

11. Marie M. Extraction of brown seaweed Padina sp. and testing the extract as a tyrosinase inhibitor. Repository IPB 2014:9.

12. Nurjanah, Nurilmala M, Anwar E, Luthfiyana N, Hidayat T. Identification of bioactive compounds of seaweed Sargassumsp. and Eucheuma cottoniidoty as a raw sunscreen cream. Proc Pak Acad Sci 2017:54:311-8

13. Syamsul ES, Andani F, Soemarie YB. Analgesic test in etanolik and kerahau extract in white rat. Trad Med 2016;21:99-103.

14. Asmawati A, Hasyim R, Lianingsih AI, Ariani DF. The difference of anti-inflammatory effect of brown algae extract Padina sp. and Sargassum sp. that is derived from Punaga Beach, South Sulawesi. J Dentomaxillofac Sci 2016;1:109-12.

15. Pati MP, Sharma SD, Nayak L, Panda CR. Uses of seaweed and its application to human welfare: A review. Int J Pharm Pharm Sci $2016 ; 8: 12-20$ 